\title{
Caregiving burden in schizophrenia: Is hospital admission effective in reducing it?
}

\author{
Mishra SK' ${ }^{1}$ Pandey AK², Adhikari BR ${ }^{3}$, Nepal S1
}

1. Assistant Professor, Department of Psychiatry, BPKIHS, 2 Professor, Department of Psychiatry, BPS Government College for Women, Sonepat, Haryana, 3 Professor, Department of Psychiatry, BPKIHS

$\underline{E-m a i l * C o r r e s p o n d i n g ~ a u t h o r: ~ s a n j e e v 10317 @ g m a i l . c o m}$

\section{Abstract}

Introduction: Caregivers of patients with schizophrenia suffer from significant physical and emotional turmoil. Very less has been done to see if there is some change in their problems once the patient is treated.

Material And Method: 36 caregivers of patients with schizophrenia admitted in the psychiatry ward, BPKIHS were enrolled and assessed using BAS at admission and at discharge.

Results: The number of caregivers suffering from severe burden had gone down from 17(47.2\%) to 1(2.8\%) at discharge. There was a significant reduction in the mean scores of all domains of burden.

Conclusion: The caregivers suffered from significantly less burden at discharge. However, they need continuous support throughout the treatment period as burden was reduced but not absent.

Keywords: Caregiving Burden, Schizophrenia, Nepal

\section{INTRODUCTION}

Living with a person with schizophrenia can have drastic consequences for their caretakers. Researches done in this aspect can be divided into three distinct periods. 1 The first period started in the 1950s when researchers described in detail all the different consequences for family members with particular attention to negative aspects. In the second period starting in early 1970s, instruments were developed and used in studies that compared community approaches with the more classical approaches. The third period began in the early 1980s when interventions or treatment programmes with a psycho-educational approach which aimed at reduction of family burden, stress or experienced emotion became the central point of interest. Recently, a fourth period has started, with the emphasis on relatives' needs, perceptions and attributions, coping style and mental health. ${ }^{1}$

One of the first studies done in this regard stated "almost no systematically collected data exist to permit analysis of what happens within the family group when a member develops a mental illness". ${ }^{2}$ This created the pathway for many different such researches and they have consistently shown that caregivers of patients with schizophrenia suffer from a significant amount of burden. ${ }^{3-9}$ This burden can be experienced in various areas such as disturbed routines, financial difficulties, physical problems, tense relationships, experiencing anger and grief.7-10

So far the studies have shown that burden does exist among the caregivers but very few have tried to see what happens to it once the patient is treated. Those that have attempted it have have used periods of intervention ranging from 9 months to 2 years. ${ }^{11-13}$ There is scarcity of literature about the effect of brief psychoeducation on caregiver burden. This study is an attempt to see if there is any change in the burden experienced following admission and treatment of the patient.

MATERIAL AND METHOD 
This is a descriptive and cross sectional study conducted among caregivers of patients with schizophrenia admitted in the psychiatry ward of BPKIHS during a period of one year (January 2013 to December 2013). A total of 36 caregivers were enrolled after obtaining informed written consent. A semi-structured pro-forma was used to obtain information about the sociodemographic characters of the caregivers. Caregivers were assessed using the Burden Assessment Schedule (BAS). BAS is in English language and therefore, translation and back translation was done to obtain a Nepali language scale. Assessment of caregivers was done twice. The first assessment was done within 48 hours of admission and the second assessment was done at the time of discharge. The process of psychoeducating the caregivers started from the time of admission and continued till discharge.

The collected data was entered in MicrosoftExcel 2007 and converted into SPSS 11.5 for statistical analysis. Descriptive statistics were analysed using mean, standard deviation, number and percentage while for inferential statistics chi square and paired $t$ test was used.

\section{RESULT}

The mean age of the caregivers was found to be $42.8 \pm 14.8$ years. Most of them were in the age group 18-30 years while 5(13.9\%) were above 60 years old. $19(52.8 \%)$ of the caregivers were male while $17(47.2 \%)$ were females. Hinduism was the most common religion followed. Majority of the caregivers had not received any formal education and $29(80.6 \%)$ of them were married. Most of the caregivers were siblings of the patients followed by fathers and mothers. The sociodemographic characteristics of the caregivers has been shown in table 1 .

Using BAS it was found that $17(47.2 \%)$ of caregivers suffered from severe burden at the time of admission while only $1(2.8 \%)$ reported as suffering from severe burden at the time of discharge.(chi square 14.22, $\mathrm{p}<0.001$ ). The three most severely affected areas at admission were physical and mental health, taking responsibility and patient's behavior. 35(69.4\%) caregivers each reported severe burden regarding physical and mental health and taking responsibility while $24(66.7 \%)$ reported being severely distressed due to patient's behaviour.

Table 1: Socio-demographic Characteristics Of the Caregivers

\begin{tabular}{|c|c|c|}
\hline \multicolumn{2}{|c|}{ Variable } & Caregivers \\
\hline \multicolumn{2}{|c|}{ Mean Age \pm SD (years) } & $42.8 \pm 14.8$ \\
\hline \multirow{5}{*}{$\begin{array}{c}\text { Age } \\
\text { distribution } \\
\text { No. }(\%)\end{array}$} & $18-30$ & $11(30.6)$ \\
\hline & $31-40$ & $7(19.4)$ \\
\hline & $41-50$ & $7(19.4)$ \\
\hline & $51-60$ & $6(16.7)$ \\
\hline & Above 60 & $5(13.9)$ \\
\hline \multicolumn{2}{|c|}{ Total } & $36(100.0)$ \\
\hline \multirow{2}{*}{$\begin{array}{l}\text { Gender } \\
\text { No. }(\%) \\
\end{array}$} & Male & $19(52.8)$ \\
\hline & Female & $17(47.2)$ \\
\hline \multicolumn{2}{|c|}{ Total } & 36(100.0) \\
\hline \multirow{4}{*}{$\begin{array}{l}\text { Religion } \\
\text { No. }(\%)\end{array}$} & Hindu & $30(80.3)$ \\
\hline & Buddhist & $1(2.8)$ \\
\hline & Christian & $1(2.8)$ \\
\hline & Others (Kirat) & $4(11.1)$ \\
\hline Total & & $36(100.0)$ \\
\hline \multirow{6}{*}{$\begin{array}{c}\text { Education } \\
\text { No. }(\%)\end{array}$} & Illiterate & $12(33.3)$ \\
\hline & Primary & $3(8.3)$ \\
\hline & Middle & $6(16.7)$ \\
\hline & SLC & 513.9) \\
\hline & Intermediate & $4(11.1)$ \\
\hline & Graduate & $6(16.7)$ \\
\hline \multicolumn{2}{|c|}{ Total } & $36(100.0)$ \\
\hline \multirow{7}{*}{$\begin{array}{c}\text { Occupation } \\
\text { No. }(\%)\end{array}$} & Business & $2(5.6)$ \\
\hline & Farmer & $13(36.1)$ \\
\hline & Labourer & $4(11.1)$ \\
\hline & Service & $5(13.9)$ \\
\hline & Housewife & $7(19.4)$ \\
\hline & Student & $2(5.6)$ \\
\hline & Unemployed & $3(8.3)$ \\
\hline \multicolumn{2}{|c|}{ Total } & $36(100.0)$ \\
\hline \multirow{2}{*}{$\begin{array}{l}\text { Marital status } \\
\text { No. (\%) }\end{array}$} & Bachelor & $7(19.4)$ \\
\hline & Married & $29(80.6)$ \\
\hline \multicolumn{2}{|c|}{ Total } & $36(100.0)$ \\
\hline \multirow{5}{*}{$\begin{array}{c}\text { Relation to } \\
\text { patient } \\
\text { No. }(\%)\end{array}$} & Father & $8(22.2)$ \\
\hline & Mother & $7(19.4)$ \\
\hline & Spouse & $9(25.0)$ \\
\hline & Sibling & $11(30.6)$ \\
\hline & Other (Uncle) & $1(2.8)$ \\
\hline \multicolumn{2}{|l|}{ Total } & $36(100.0)$ \\
\hline
\end{tabular}


At discharge the number of patients experiencing severe burden in these areas had reduced to $6(16.7 \%)$ (chi square $11.65, \mathrm{p} .001$ ), $8(22.2 \%) \quad$ (chi square 22.15, $\mathrm{p}<0.001$ ) and $4(11.1 \%)$ (chi square $14.29, \mathrm{p}<0.001)$ respectively. The number of caregivers experiencing severe burden in all other domains had reduced. (Table 2)

Table 2: Assessment of caregiver burden at admission and discharge

\begin{tabular}{|c|c|c|c|}
\hline & $\begin{array}{c}\text { Assessment } \\
\text { of severity }\end{array}$ & $\begin{array}{c}\text { Admission } \\
\text { No. }(\%)\end{array}$ & $\begin{array}{c}\text { Discharge } \\
\text { No.(\%) }\end{array}$ \\
\hline \multirow{3}{*}{ Total burden } & None & $0(0)$ & $0(0)$ \\
\hline & $\begin{array}{c}\text { To some } \\
\text { extent }\end{array}$ & 19(52.8) & $35(97.2)$ \\
\hline & Very much & $17(47.2)$ & $1(2.8)$ \\
\hline \multirow{3}{*}{$\begin{array}{l}\text { Spouse } \\
\text { related }\end{array}$} & None & $0(0)$ & $6(66.7)$ \\
\hline & $\begin{array}{c}\text { To some } \\
\text { extent }\end{array}$ & $4(44.4)$ & $2(22.2)$ \\
\hline & Very much & $5(55.6)$ & 1(11.1) \\
\hline \multirow{3}{*}{$\begin{array}{l}\text { Physical and } \\
\text { mental health }\end{array}$} & None & $0(0)$ & $3(8.3)$ \\
\hline & $\begin{array}{c}\text { To some } \\
\text { extent }\end{array}$ & 11(30.6) & $27(75.0)$ \\
\hline & Very much & $25(69.4)$ & $6(16.7)$ \\
\hline \multirow{3}{*}{$\begin{array}{l}\text { External } \\
\text { support }\end{array}$} & None & $0(0)$ & $5(13.9)$ \\
\hline & $\begin{array}{c}\text { To some } \\
\text { extent }\end{array}$ & $30(83.3)$ & $30(83.3)$ \\
\hline & Very much & $6(16.7)$ & $1(2.8)$ \\
\hline \multirow{3}{*}{$\begin{array}{l}\text { Caregiver's } \\
\text { routine }\end{array}$} & None & $1(2.8)$ & $5(13.9)$ \\
\hline & $\begin{array}{c}\text { To some } \\
\text { extent }\end{array}$ & $12(33.3)$ & $31(86.1)$ \\
\hline & Very much & $23(63.9)$ & $0(0)$ \\
\hline \multirow{3}{*}{$\begin{array}{c}\text { Support of } \\
\text { patient }\end{array}$} & None & $1(2.8)$ & $1(2.8)$ \\
\hline & $\begin{array}{c}\text { To some } \\
\text { extent }\end{array}$ & $17(47.2)$ & $27(75.0)$ \\
\hline & Very much & $18(50.0)$ & $8(22.2)$ \\
\hline \multirow{3}{*}{$\begin{array}{c}\text { Taking } \\
\text { responsibility }\end{array}$} & None & $0(0)$ & $5(13.9)$ \\
\hline & $\begin{array}{c}\text { To some } \\
\text { extent }\end{array}$ & 11(30.6) & $30(83.3)$ \\
\hline & Very much & $25(69.4)$ & $1(2.8)$ \\
\hline \multirow{3}{*}{$\begin{array}{l}\text { Other } \\
\text { relations }\end{array}$} & None & $3(8.3)$ & $4(11.1)$ \\
\hline & $\begin{array}{c}\text { To some } \\
\text { extent }\end{array}$ & $14(38.9)$ & $24(66.7)$ \\
\hline & Very much & $19(52.8)$ & $8(22.2)$ \\
\hline \multirow{3}{*}{$\begin{array}{l}\text { Patient's } \\
\text { behaviour }\end{array}$} & None & $0(0)$ & $2(5.6)$ \\
\hline & $\begin{array}{c}\text { To some } \\
\text { extent }\end{array}$ & $12(33.3)$ & $30(83.3)$ \\
\hline & Very much & $24(66.7)$ & $4(11.1)$ \\
\hline \multirow{3}{*}{$\begin{array}{l}\text { Caregiver's } \\
\text { strategy }\end{array}$} & None & $0(0)$ & $3(8.3)$ \\
\hline & $\begin{array}{c}\text { To some } \\
\text { extent }\end{array}$ & $16(44.4)$ & $31(86.1)$ \\
\hline & Very much & $20(55.6)$ & $2(5.6)$ \\
\hline
\end{tabular}

The mean BAS score which was $81.3 \pm 15.9$ at admission at admission has reduced to $57.2 \pm$ 11.1 at discharge. There was a significant reduction of scores in all domains of BAS. (Table 3)

Table 3: Mean BAS scores at admission and discharge

\begin{tabular}{|l|c|c|c|c|}
\hline \multicolumn{1}{|c|}{ BAS } & $\begin{array}{c}\text { Admission } \\
\text { (Mean } \pm \\
\text { SD) }\end{array}$ & $\begin{array}{c}\text { Discharge } \\
\text { (Mean } \pm \\
\text { SD) }\end{array}$ & $\begin{array}{c}\text { Mean } \\
\text { difference }\end{array}$ & $\begin{array}{c}\text { P } \\
\text { value }\end{array}$ \\
\hline Total burden & $81.3 \pm 15.9$ & $57.2 \pm 11.1$ & -24.1 & $<0.05$ \\
\hline Spouse related & $9.0 \pm 2.4$ & $6.0 \pm 1.6$ & -3.0 & $<0.05$ \\
\hline $\begin{array}{l}\text { Physical and } \\
\text { mental health }\end{array}$ & $14.2 \pm 3.0$ & $9.3 \pm 2.4$ & -4.9 & $<0.05$ \\
\hline $\begin{array}{l}\text { External } \\
\text { support }\end{array}$ & $10.6 \pm 3.3$ & $8.5 \pm 2.6$ & -2.1 & $<0.05$ \\
\hline $\begin{array}{l}\text { Caregiver's } \\
\text { routine }\end{array}$ & $11.4 \pm 2.8$ & $6.8 \pm 1.5$ & -4.6 & $<0.05$ \\
\hline $\begin{array}{l}\text { Support of } \\
\text { patient }\end{array}$ & $8.6 \pm 2.0$ & $7.1 \pm 1.7$ & -1.5 & $<0.05$ \\
\hline $\begin{array}{l}\text { Taking } \\
\text { responsibility }\end{array}$ & $9.2 \pm 1.8$ & $6.4 \pm 1.6$ & -2.8 & $<0.05$ \\
\hline $\begin{array}{l}\text { Other } \\
\text { relations }\end{array}$ & $9.6 \pm 2.0$ & $6.5 \pm 1.7$ & -3.1 & $<0.05$ \\
\hline $\begin{array}{l}\text { Patient's } \\
\text { behaviour }\end{array}$ & $8.7 \pm 1.9$ & $6.2 \pm 1.4$ & -2.5 & $<0.05$ \\
\hline $\begin{array}{l}\text { Caregiver's } \\
\text { strategy }\end{array}$ & $5.3 \pm 1.5$ & -1.2 & $<0.05$ \\
\hline
\end{tabular}

\section{DISCUSSION:}

Caregivers in schizophrenia suffer from burden in several different areas. This has detrimental effects for both caregivers and patients. Higher level of burden results in decreased ability of the caregiver to function effectively which ultimately leads to patient's needs being unmet, early institutionalization of the patients and deterioration in the physical and psychological health of the caregiver. ${ }^{1}$ The patients and caregivers can thus be seen as trapped in a vicious cycle where both patients' symptoms and caregivers' burden tend to increase each other. This makes addressing the issue of burden even more important.

There are a number of studies that show the burden suffered by the caregivers. But it was only in the 1970s that awareness grew among family members and their advocacy organizations that living with an illness like schizophrenia is difficult and confusing for patients and families alike. Even with this new perspective, it took over 10 years to revive the interest and effort in involving family members 
in the treatment process. The group of interventions that emerged became known as family psychoeducation. ${ }^{14}$ The effectiveness of these interventions in reducing caregiver burden has been demonstrated in different studies. ${ }^{11-13}$ While these studies involved long term interventions, the participants in our study received brief period of psychoeducation. The mean duration of hospitalization in our study was 32.8 days (SD - 16.2) which was also the period for which the family members were educated about various aspects of schizophrenia. We found that this brief period of family intervention was also effective in reducing the burden. Further, the caregivers did not receive any structured form of psychotherapy sessions. They were provided with the usual psychoeducation that we routinely practice in our setting and we found that even with this basic psychoeducation there was significant reduction in the burden experienced by them. The findings from our study show that involving family members in the treatment process from an early stage and providing simple education about illness can also help in alleviating their problems. However the process should not end here. From our results, caregivers still suffered from some burden at discharge. This was more for areas like supporting the patient and disruption of relations. Hence, it is important to involve the family members throughout the treatment program in order to alleviate their suffering.

The limited sample size is one of the major drawbacks of our study and further studies with larger sample size is required to corroborate the findings of this study.

\section{CONCLUSION:}

Caregivers of patients with schizophrenia play an important role in their lives. They often assume many responsibilities for looking after the patients. All these added responsibilities result in a significant amount of burden. This study showed that the psychoeducation that family members receive during the period of admission is significantly effective in reducing the burden highlighting the importance of early involvement of family members in the treatment process.

\section{ACKNOWLEDGEMENT:}

The authors would like to thank all the caregivers who participated in the study and the entire department of psychiatry, BPKIHS for helping to conduct this study.

\section{REFERENCES:}

1. Deeken et al. Care for the caregivers: a review of the self-report instruments developed to measure burden, needs and quality of life of informal caregivers. Journal of Pain and Symptom Management 2003;26(4):922-953

2. Clausen JA and Yarrow MR. The impact of mental illness in the family. Journal of Social Issues 1955;11:3-64

3. Mills, E. Living with Mental Illness a study from East London, etc. $1^{\text {st }}$ ed. Routledge and Kegan Paul:London;1962

4. Wing et al. Morbidity in the community of schizophrenic patients discharged from London mental hospitals in 1959. The British Journal of Psychiatry 1964;110(464):10-21

5. Waters MA, Northover J. Rehabilitated long term schizophrenics in the community. The British Journal of Psychiatry 1965;111:258-267

6. Leff et al. A controlled trial of social intervention in the families of schizophrenic patients. The British Journal of Psychiatry 1982;141:121-134

7. Magliano et al. Burden on the families of patients with schizophrenia: results of the BIOMED I study. Social Psychiatry and Psychiatric Epidemiology 1998;33(9):405-412

8. Hassan et al. Burden and coping strategies in caregivers of schizophrenic patients. Journal of American Science 2011;7(5):802-811

9. Tan et al. Burden and coping strategies experienced by caregivers of patients with schizophrenia in the community. Journal of Clinical Nursing 2012;21:2410-2418

10. Provencher HL. Objective burden among primary caregivers of persons with chronic schizophrenia. Journal of Psychiatric and Mental Health Nursing 1996;3(3):181-187

11. Falloon et al. Family management in the prevention of morbidity of schizophrenia: the adjustment of the family unit. The British Journal of Psychiatry 1985;147:156-163

12. Mingyuan et al. Effectiveness of psychoeducation of relatives of schizophrenics patients: A prospective cohort study in five cities of China. International Journal of Mental Health 1993;32(1):47-49

13. McFarlene et al. A comparison of two levels of family-aided assertive community treatment. Psychiatric Services 1996;47(7):744-750

14. McFarlene et al. Family psychoeducation and schizophrenia: A review of literature. Journal of Marital and Family Therapy 2003;29(2):223-245 